\title{
Primordial germ cell migration and the Wnt signaling pathway
}

\author{
Andrea V. Cantú, Diana J. Laird \\ Department of $\mathrm{Ob} / \mathrm{Gyn}$ and Reproductive Sciences, Center for Reproductive Sciences, Eli and Edythe Broad Center for \\ Regeneration Medicine \& Stem Cell Research, San Francisco, CA, USA.
}

\begin{abstract}
A critical step in the development of gametes is the migration of their primordial germ cell (PGC) precursors to the forming gonads. Although the location and mode of PGC specification differs between organisms, the formation of a committed germline before organogenesis creates a need for migration through the growing embryo in order to reach the site of gonadogenesis. Failure of PGC migration can, in many cases, compromise fertility or conversely lead to the formation of teratomas in sites outside of the gonad. Here we review the mechanism of migration employed by PGCs and compare the timing and routes across several model organisms. We summarize recent work on the role of the Wnt signaling pathway in cell migration and the lineage specific function in PGCs, mainly through the ligand Wnt5a and its receptor Ror2.
\end{abstract}

Keywords: cell migration, primordial germ cell, Ror2, Wnt signaling, Wnt5a.

\section{Introduction}

Although the egg and sperm are not used until adulthood, their precursors, the primordial germ cells (PGCs), are among the first lineages established in development (Laird et al., 2008). Due to their critical role in preserving genomic integrity and transmitting genetic information to the next generation, the development of PGCs from their initial specification to final maturation has been studied in multiple species to identify the processes and pathways that safeguard their reproductive function. In all model organisms studied thus far, the PGCs are specified far from their ultimate residence in the gonads; thus, they must initiate and complete a lengthy migration through the developing embryo from their point of origin to reach the gonadal primordia (Richardson and Lehmann, 2010). An adequate supply of gametes depends upon the successful migration of PGCs during embryogenesis, with the failure to complete this journey resulting in infertility and an increased risk of teratoma development. Therefore, precise control of PGC movement, interactions with a diversity of cellular environments, and survival en route to the gonad is essential for ensuring the reproductive success of an organism. Here we review cell migration as it relates to the germline. We examine and compare the developmental timing and cellular routes of PGC migration in multiple species, as well as explore the molecular signaling that controls this process, with a particular emphasis on the Wnt pathway.

\section{Cell migration in development}

Cell migration is vital for development and survival and has been observed in the simplest to most complex multicellular organisms. A number of events have been identified in the coordination of cell motility including asymmetric polarization, protrusion formation at the leading edge, cell adhesion, and translocation or retraction of the lagging edge (Izzard and Lochner, 1980; Chen, 1981; Coates et al., 1992; Lauffenburger and Horwitz, 1996; Chen et al., 2003). There are many types of motile cells which each deploy unique and context-dependent signaling pathways to mediate these fundamental processes; however, nearly all forms of migration require reorganization of the actin cytoskeleton and integrin binding to the extracellular matrix (ECM). External cues such as extracellular substrate stiffness, combinations of secreted factors, and two versus three-dimensional surroundings are also important in regulating cell migration (Pelham and Wang, 1997; Lo et al., 2000; Lämmermann et al., 2008; Hynes, 2009; Pathak and Kumar, 2012; Charras and Sahai, 2014).

The two major categories of cell movement are collective cell migration and single cell migration. The primary task of each mode of migration differs substantially - collective migration drives the assembly, form, and regeneration of complex tissues and organs and single cell migration allows cells to move between locations, to integrate into tissues or perform effector functions (Friedl and Wolf, 2010).

\section{Collective cell migration}

The most common form of cell movement during development is collective cell migration, a process defined by the coordination and cooperation of neighboring cells to move together as a group. Collective cell migration has been observed in epithelial tissues such as the lateral line primordium in zebrafish or mammalian vasculature (Metcalfe, 1985; Rousseau et al., 1997) as well as mesenchymal cohorts like those of the neural crest in Xenopus and mouse (Serbedzija et al., 1990; Collazo et al., 1993). Despite the use of different molecular and genetic pathways depending on cell type and species, the underlying principles of collective cell migration are conserved. The defining feature of this form of cell movement is the maintenance of stable cell-cell contacts between neighboring motile cells (Hegerfeldt et al., 2002; Ulrich et al., 2005; Llense and Martín-Blanco, 2008). Through these interactions, cells of the collective are able to

${ }^{1}$ Corresponding author: diana.laird@ucsf.edu 
specialize leaders and followers, propagate directional cues, and maintain polarity within the group (Scarpa and Mayor, 2016). Cells that move together have increased efficiency of migration as compared to cells that move individually, because they can collectively buffer heterogeneity in cell responsiveness to maintain direction and substantially remodeling the extracellular environment to form a clear route for the follower population (Vitorino and Meyer, 2008; Gjorevski et al., 2015). To more easily define and manipulate the mechanisms of collective cell migration, in vitro models of wound healing, matrix invasion, and planar cell polarity have been developed using fibroblasts, migratory cell lines, or primary cells (Friedl and Gilmour, 2009).

\section{Single cell migration}

While many classical studies of cell movement used models of collective cell migration, there are several examples of cells that migrate singly in development, homeostasis, and disease. In the embryo, hematopoietic stem cells, immature neurons, and PGCs migrate as single cells from their point of specification to their final location (Chiquoine, 1954; Berry and Rogers, 1965; Johnson and Moore, 1975; Forrester and Garriga, 1997). In adult homeostasis, leukocytes survey the body for wounding and infection by migrating through various tissues and the vasculature (de Bruyn, 1946; Miller et al., 2003; Weninger et al., 2014). In cancer, metastatic cells move out of the primary tumor by hijacking components of the migratory network to colonize new sites around the body (Clark and Vignjevic, 2015).

The movement of single cells is similar in general principle to movement by groups of cells - they must polarize, sense chemotactic signals, and form adhesions with their extracellular surroundings; however, in contrast to collect cell migration, each individually migrating cell must be capable of all functions. This often results in higher cell velocities, because there is no negotiation with neighboring cells, but lower overall efficiency of directed migration, since single cells are more susceptible to subtle changes in extracellular signaling and thus more likely to wander. In vitro culture assays are currently being used to study how individual cells interact with the extracellular compartment and simultaneously control the multitude of processes that allow for motility.

\section{Primordial germ cell migration}

\section{Conservation of primordial germ cell migration}

In many species, the PGCs are among the earliest cell lineages specified in the embryo, often set aside prior to gastrulation and far from their ultimate residence in the gonads (Chiquoine, 1954; Ephrussi and Lehmann, 1992; Yoon et al., 1997). Thus, PGCs must undergo a lengthy and active migration through the developing embryo to reach the somatic cells of the developing gonads (Fig. 1; Richardson and Lehmann, 2010). Fertility in the adult relies upon the successful migration of the germline; failure to complete this process results in a loss of functional germ cells and increased risk for the development of germ cell tumors (Mintz and Russell, 1957; McCoshen and McCallion, 1975; Chaganti et al., 1994). Through the study of multiple model organisms, it has been shown that the overall process of PGC migration - interaction with multiple tissue types, receptivity to and sensing of chemoattractant and repellant cues - is highly conserved, and several key genes and signaling pathways have been identified (Richardson and Lehmann, 2010).

In Drosophila melanogaster (fruit fly), the process of PGC migration is completed within $4 \mathrm{~h}$ (Sonnenblick, 1941; Starz-Gaiano and Lehmann, 2001). During gastrulation, the PGCs are passively carried into the midgut pocket of the developing embryo (Jaglarz and Howard, 1995). Shortly thereafter, the PGCs begin to express Tre1, which polarizes the cells and initiates their individual dispersal through the epithelial layer midgut endoderm (Fig. 1; Kunwar et al., 2008). Once outside the midgut, Drosophila PGCs migrate dorsally then anteriorly along the midgut, incorporate into the posterior mesoderm, and bifurcate laterally to join somatic gonadal precursor cells (SGPCs) and form the gonads (Sonnenblick, 1941; Warrior, 1994). This migratory route is defined by the precise expression of Wunens (Wun, Wun2) in the neighboring somatic tissues, such as the midgut, which act as repellant signals to guide PGCs toward the SGPCs and restrict movement into ectopic locations (Zhang et al., 1996, 1997; Starz-Gaiano et al., 2001). Later-stage migration to the lateral mesoderm and eventual association with the SGPCs is directed by the expression of Hmgcr, an enzyme important in cholesterol and isoprenoid synthesis, and Mdr49, an export protein, in the soma; however, the identity of the chemoattractant produced and secreted by these proteins has yet to be determined (Van Doren et al., 1998; Ricardo and Lehmann, 2009). Motility in Drosophila PGCs is mediated by the downregulation of DE-cadherin and formation of actinrich leading and lagging edges to coordinate protrusion, adhesion, and retraction of the cells (Jaglarz and Howard, 1995; Kunwar et al., 2008).

Another well-studied model for PGC migration is Danio rerio (zebrafish). Over the course of $18 \mathrm{~h}$, zebrafish PGCs embark on a complex journey through a series of intermediate targets on their way to the final location of the gonad (Weidinger et al., 1999, 2002). Following their specification in four random locations throughout the embryo (Yoon et al., 1997; reviewed in Raz, 2003), a feature unique to zebrafish development, the PGCs migrate to the dorsal side of the embryo, are excluded from the midline, align with the anterior and lateral mesoderm, and coalesce into two lateral clusters which are moved posteriorly to their final position at the site of gonad formation (Weidinger et al., 1999). Coordination of this movement is mediated primarily by the chemoattractant SDF1 (also known as CXCL12), which has a spatially and temporally dynamic expression that is tightly regulated in somatic tissues that comprise the migratory route (Doitsidou et al., 
2002; Knaut et al., 2003). Additionally, the isoprenoid arm of Hmger pathway is important in zebrafish PGC migration, although its exact mechanism of action has not been elucidated (Thorpe et al., 2004). Unlike germ cells in other organisms which polymerize actin and modify the cytoskeleton to form protrusions at the leading edge, PGCs in the zebrafish embryo employ membrane blebbing and cytoplasmic flow as a core means of their motility (Blaser et al., 2006). The PGCs switch between periods of active and directional movement termed "running," and "tumbling," or pauses in movement characterized by environment-sensing via multiple membrane blebs and reorientation toward the chemotactic signal guiding their migration to the gonads (Reichman-Fried et al., 2004). This style of migration is considered to be a strategy for PGCs to move forward via cytoplasmic translocation when adhesions with the surrounding microenvironment are overly stable or cannot be altered quickly enough to permit more traditional movement (Paluch and Raz, 2013).

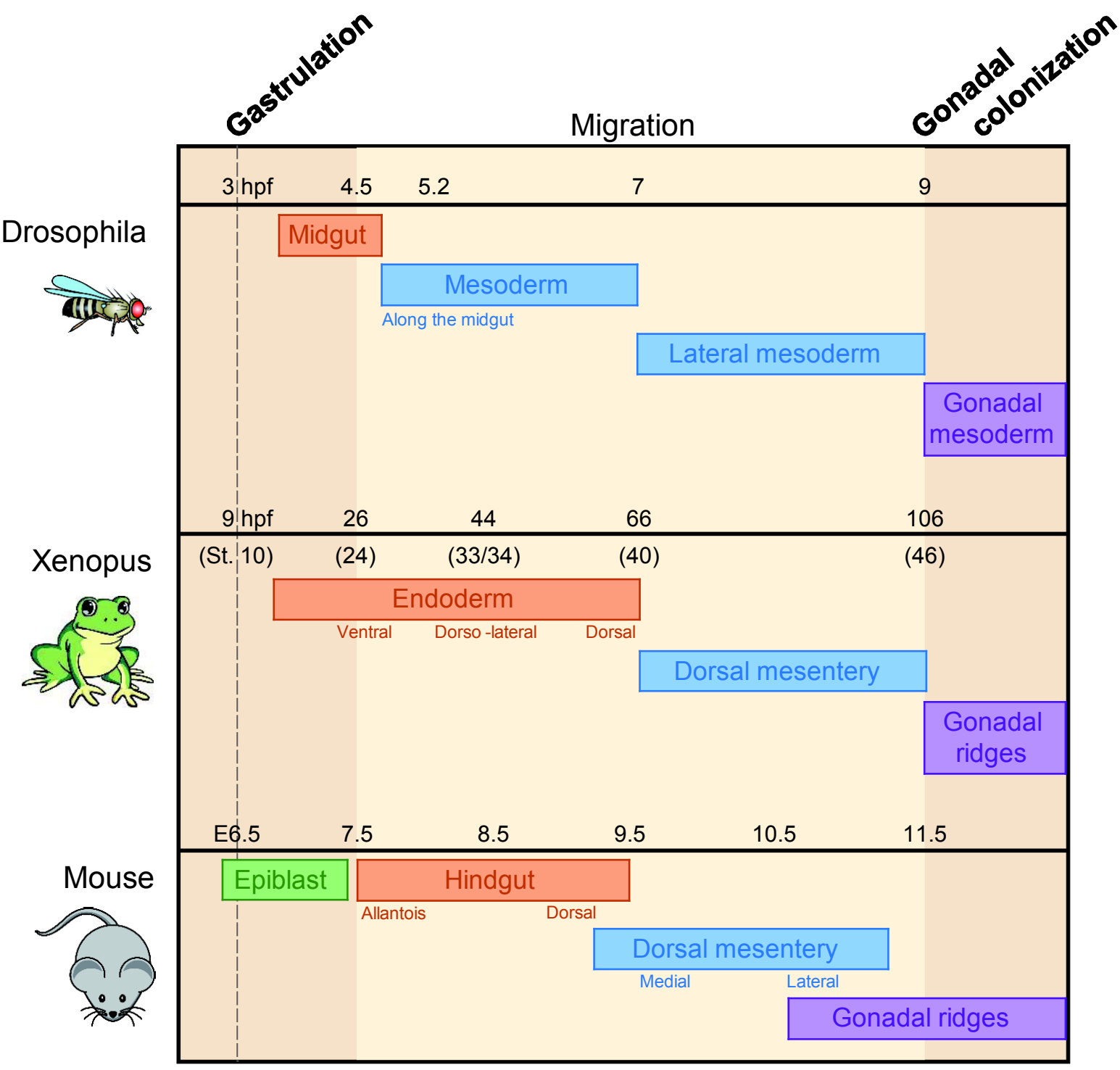

Figure 1. Conservation of PGC migration between multiple species. Following gastrulation (dashed line), PGCs in Drosophila, Xenopus, and mouse undergo lengthy migrations through endodermal sheets (orange) and mesodermal tissues (blue) to reach the developing gonads (purple). Time scales of the migratory period are noted for each species; hpf $=$ hours post-fertilization, $\mathrm{E}=$ embryonic day. Annotations underneath each bar represent specific locations and patterns of movement through that region.

Other model organisms in which PGC migration has been described, but not yet rigorously studied, include Gallus gallus (chicken) and Xenopus laevis (frog). In the chicken, PGCs are moved passively by gastrulation to the germinal crescent, the region of extraembryonic tissue anterior to the head. From the germinal crescent they concentrate in the sinus terminalis, enter the embryonic vasculature via the vitelline veins, and utilize the circulatory system to reach the developing gonadal soma in the intermediate mesoderm (Nakamura et al., 2007; de Melo Bernardo et al., 2012). This process occurs over approximately 1.5 days, from stages 9 to 17 of embryonic development. The presence of protrusions on chick PGCs in the 
mesoderm (Nakamura et al., 2007) and the similarities in movement with leukocytes during inflammation (reviewed in Weninger et al., 2014) suggest that migration through the endothelium and within the mesoderm is an active process. In situ hybridization revealed high levels of SDF1 expression in the mesodermal tissues of later chick PGC migration and concordant expression of CXCR4 on the germ cells (Stebler et al., 2004). Ectopic expression of SDF1 in the chick embryo re-routed many PGCs to new locations, suggesting that this chemokine guides exit of the germ cells from the vasculature and subsequent interstitial tissue movement toward the gonads (Stebler et al., 2004). Other guidance cues, mechanisms of motility, and signaling pathways important for PGC migration in the chicken embryo remain unknown.

In the frog, PGC migration spans two days of development, from stages 24 to 46 (Kamimura et al., 1976; Nishiumi et al., 2005). Following localization to the ventral endoderm during gastrulation, PGCs dissociate from their original cluster and begin actively migrating dorsally, laterally, and anteriorly through the endodermal mass (Fig. 1). Upon reaching the most dorsal region of the endoderm, they exit into the dorsal mesentery and reaggregate in the genital ridges. The chemotactic signals that direct the movement of frog PGCs have not yet been identified; however, recent work has begun to elucidate the role of adhesive properties, ECM molecules, and internal cytoskeletal dynamics in regulating the modes of PGC motility in the developing frog embryo (Nishiumi et al., 2005; Dzementsei et al., 2013; Terayama et al., 2013).

\section{$P G C$ migration in the mouse}

Due to the limiting number of PGCs in the early stages of development, much less is known about the mechanisms that regulate germ cell migration in mammals as compared to fly or zebrafish. After specification in the epiblast, mouse PGCs begin their migration on embryonic day 7.5 (E7.5) by actively entering the primitive endoderm, which will differentiate into the hindgut (Chiquoine, 1954; Clark and Eddy, 1975; Anderson et al., 2000). Over the course of several days, they integrate into and travel within the developing hindgut epithelium before crossing the basement membrane at E9.5 and invading into surrounding mesentery (Fig. 1). The PGCs then move dorsally through the elongating dorsal mesentery of the midline before bifurcating laterally and ultimately colonizing the emerging gonads from E10.5-11.5 (Molyneaux et al., 2001; Richardson and Lehmann, 2010). Once in the gonad, mouse PGCs, like other species, lose their migratory potential and initiate sex differentiation pathways (Donovan et al., 1986). Similar to the migration in all model organisms that have been studied, mammalian PGCs interact with both epithelial and mesenchymal tissues and undergo periods of active and passive movement during the migratory period.

Several secreted factors and their corresponding receptors have been identified in the promotion of motility and directional guidance of migratory mouse PGCs. The best characterized ligandreceptor pair in PGC migration is KitL (also known as Steel factor or Stem cell factor) and cKit. Early studies of mice carrying mutations in the cKit locus (also known as W) or KitL locus (also known as Steel) noted a dramatic reduction in population size of the germline as well as a delay in the migration of PGCs that resulted in failure to efficiently colonize the gonadal ridges (Mintz and Russell, 1957; McCoshen and McCallion, 1975; Buehr et al., 1993; Runyan et al., 2006). Careful characterization of KitL, which has both membranebound and secreted forms (Flanagan et al., 1991; Huang et al., 1992; Miyazawa et al., 1995), revealed its expression by somatic cells of the embryonic mesoderm and gonadal ridges to be spatially and temporally dynamic along the migratory route, creating a wave of expression coined the "traveling niche" ( $\mathrm{Gu}$ et al., 2009). While secreted KitL is present and capable of facilitating PGC movement, this wave is generated by the membrane-bound form of KitL in order to produce a localized high concentration of ligand needed to sustain and guide PGC motility (Gu et al., 2011). Addition of exogenous secreted KITL in ex vivo cell culture induces polarization and protrusion formation in migratory PGCs and drives the movement of post-migratory PGCs in embryo slice culture (Farini et al., 2007; Laird et al., 2011; Gu et al., 2011).

Conserved chemotactic pathways have also been identified in the mouse, although they are less well-studied. The SDF1-CXCR4 pathway has been established as a mediator of PGC migration (Ara et al., 2003; Molyneaux et al., 2003). Akin to its role in zebrafish, SDF1 is thought to function primarily as a chemoattractant in the later stages of migration to the gonadal ridges, as initiation of PGC migration and entry into the hindgut is unaffected by genetic loss of the ligand or receptor. In another parallel to fly and fish, the Hmgcr pathway plays a role in mouse PGC migration; however, its function is more complex and utilizes both the cholesterol and isoprenoid arms of the pathway (Ding et al., 2008).

Adhesion molecules and ECM proteins are also critical in ensuring efficient migration of PGCs to the gonads. Expression of several common ECM components has been found along the migratory route, notably collagen IV, fibronectin, and laminin in the mesentery and laminin in the basement membranes of the mouse hindgut and coelomic epithelia (De Felici and Dolci, 1989; Ffrench-Constant et al., 1991; GarcíaCastro et al., 1997). Cell culture experiments highlighted the ability of PGCs to bind each of these molecules to varying degrees depending on substrate and age of the germ cells. Loss of a major ECM binding protein, $\beta 1$-integrin, results in a migratory delay in PGCs, with a majority of mutant germ cells remaining outside the gonads at E11.5 (Anderson et al., 1999). Several $\alpha$-integrins are also known to be expressed by PGCs, but their removal does not impair migration, suggesting a redundancy in the ability to bind ECM which may correspond to the overlapping expression patterns of different ECM proteins. The one area of ECM interaction that has been understudied is the 
identification of degradation molecules that allow for PGC invasion through the basement membrane of the hindgut as well as movement within the different tissues along the migratory route, and thus, remains an open question.

In addition to the ECM, cell-cell interactions are likely important in the regulation of PGC migration. Similar to their counterparts in the fly, frog, and zebrafish (Blaser et al., 2005; Kunwar et al., 2008; Baronsky, et al., 2016), mouse PGCs express Ecadherin (Bendel-Stenzel et al., 2000; Di Carlo and De Felici, 2000), a classic mediator of cell-cell contact and stable adhesion, especially within epithelial tissues. However, distinct from these other organisms which downregulate E-cadherin prior to migration, PGCs in the mouse maintain and utilize its expression throughout their migration from the hindgut to the gonads (BendelStenzel et al., 2000; Di Carlo and De Felici, 2000). The presence of E-cadherin on PGCs during this time is puzzling given its absence in tissues beyond the hindgut; thus, it was proposed that E-cadherin is used to form a network of migrating PGCs by maintaining cellcell contact through very long and thin protrusions between germ cells (Gomperts et al., 1994). However, time lapse imaging of embryo slice cultures did not find evidence of sustained contact between PGCs as suggested by images from histological sections (Molyneaux et al., 2001), so the function of E-cadherin during migration remains a mystery.

Other key cellular processes during the migratory period in mouse PGC development

Simultaneous with their migration, PGCs are also coordinating several other cell processes important for their development. Distinct from other model organisms ( $\mathrm{Su}$ et al., 1998; Richardson and Lehmann, 2010; de Melo Bernardo et al., 2012), mammalian PGCs are actively proliferating during their migration, increasing in population size from approximately 45 cells at E7.5 to $\sim 200$ at E9.5 (Saitou et al., 2002; McLaren, 2003; Seki et al., 2007), 2500 at E11.5 (Laird et al., 2011), and peaking around 25,000 at E13.5 (Tam and Snow, 1981). The KitL-cKit pathway is one regulator of germ cell proliferation, with several genetic mutants for either ligand or receptor unable to expand their number of PGCs after specification, resulting in fertility defects (Mintz and Russell, 1957; McCoshen and McCallion, 1975; Buehr et al., 1993). Adding to its functions as a mitogen and chemoattractant, KitL has also been shown to play a role in PGC survival (Runyan et al., 2006).

In vitro cultures of migratory PGCs have confirmed the proliferation and survival functions of KitL (Godin et al., 1991; Dolci et al., 1991; Matsui et al., 1991) and identified a number of other factors important for these processes including LIF (Matsui et al., 1991), FGFs (Resnick et al., 1992; Kawase et al., 2004), SDF1 (Molyneaux et al., 2003), forskolin (De Felici et al., 1993), retinoic acid (Koshimizu et al., 1995), and TGF $\beta 1$ (Godin and Wylie, 1991). Refinement of germ cell culture conditions has led to a reduction in the factors necessary to maintain the survival of PGCs, increasing the utility of this system in identifying and testing the function of new factors in all facets of germ cell development (Laird et al., 2011).

In addition to proliferation, PGCs are also undergoing epigenetic reprogramming via several different mechanisms during their migration to the gonadal ridges (Seki et al., 2005). This reprogramming is thought to be critical for PGC development and function, by preventing differentiation down somatic lineages, maintaining the expression of pluriopotency genes, and erasing imprinted marks to allow for their reset during the process of gametogenesis (Ancelin et al., 2006; De Felici, 2011; Seisenberger et al., 2012; Hackett et al., 2013). Shortly after specification, levels of DNA methylation and the types of histone marks found in PGCs are indistinguishable from their somatic neighbors (Seki et al., 2005, 2007). However, as the PGCs proceed through migration, they begin to demethylate cytosines in $\mathrm{CpG}$ islands across their genome, resulting in distinctly different epigenetic patterning at E11.5 than that seen at E8.0 or in the somatic cells (Kafri et al., 1992; Seki et al., 2005; Seisenberger et al., 2012; Hackett et al., 2013). This process of demethylation is not indiscriminate, as several post-migratory PGC genes, including Vasa, Scp3, and Dazl, imprinted genes, and retrotransposons remain highly methylated until after gonadal colonization (Maatouk et al., 2006; Hackett et al., 2012; Seisenberger et al., 2012). Additionally, the histone modifications that occur during migration, including erasure of $\mathrm{H} 3 \mathrm{~K} 9 \mathrm{me} 2$ and addition of $\mathrm{H} 3 \mathrm{~K} 27 \mathrm{me} 3$ and H4/H2AR3me2, appear to move the genome toward greater transcriptional plasticity while preventing inappropriate differentiation (Seki et al., 2005; Ancelin et al., 2006). It remains unclear if this phase of epigenetic reprogramming is linked to PGC migration and movement through different somatic microenvironments or intrinsically regulated by developmental timing, and insufficient numbers of PGCs during this period have prevented the use of experimental techniques typical in this line of research. However, it may be possible to parse the question of intrinsic timing versus somatic control by examining the epigenetic status of PGCs in migration mutants in which germ cells are found in the wrong place at the wrong time.

\section{Noncanonical Wnt signaling in cell migration}

\section{Canonical versus noncanonical Wnt signaling}

Wnt signaling is one of the most commonly utilized and well-studied pathways in development. The Wnt family of genes was originally discovered in a screen for proto-oncogenes in mammary cancer (Nusse and Varmus, 1982). Characterization of this original Wnt, Wnt1 (formerly known as Int1) identified the transcription factor $\beta$-catenin as a key effector of its signaling pathway (McMahon and Moon, 1989; McCrea et al., 1993; Young et al., 1998; Mizushima et al., 2002). The ensuing identification of more Wnt family members 
and their downstream pathways led to the classification of two distinct arms of the Wnt pathway: canonical, $\beta$ catenin-mediated signaling and noncanonical, non- $\beta$ catenin-mediated signaling (Niehrs, 2012).

Canonical Wnt signaling is defined by its activity in the "on" or "off state." In the "off state" of signaling, cytoplasmic $\beta$-catenin is bound by the AxinGSK3 $\beta$-APC-CK1ع complex, phosphorylated, and degraded (Hart et al., 1998; Logan and Nusse, 2004). However, engagement of Frizzled and LRP receptors by Wnt ligands turns "on" the pathway, causing dissociation of this degradation complex. This allows $\beta$ catenin to accumulate in the cytoplasm and translocate to the nucleus, where it binds transcription factors in the $\mathrm{LEF} / \mathrm{TCF}$ family and induces gene expression (Behrens et al., 1996; Molenaar et al., 1996; Niehrs, 2012). This arm of the pathway regulates cell specification and fate decisions, organogenesis, and proliferation (Gat et al., 1998; Korinek et al., 1998; Wang et al., 2012).

Noncanonical Wnt signaling is an allencompassing term for Wnt pathways that do not work through $\beta$-catenin, of which there are many. In these pathways, Wnts commonly engage Frizzled and nonLRP receptors, such as Ror or Ryk family members (Hikasa et al., 2002; Oishi et al., 2003; Wouda et al., 2008), and activate a variety of downstream signaling pathways (Nishita et al., 2010a; Niehrs, 2012). Regulation of planar cell polarity is the best studied function of noncanonical Wnt signaling; however, these pathways can also regulate multiple mechanisms of cell migration and invasion as well as inhibit the canonical Wnt pathway (Mikels and Nusse, 2006; Nishita et al., 2006; Enomoto et al., 2009; Mikels et al., 2009).

While early studies attempted to classify Wnts and their binding partners as canonical or noncanonical, recent work suggests that the context of receptors and ligands determines the predominant downstream signaling pathway in an individual cell (van Amerongen and Nusse, 2009; van Amerongen et al., 2012). This promiscuity of Wnt function can thus explain their broad expression throughout development and ability to regulate many cell types and processes at the same time.

\section{Wnt signaling in germ cell development}

Several Wnt ligands have been implicated in PGC development in the mouse: Wnt3 and Wnt3a in specification (Ohinata et al., 2009; Bialecka et al., 2012; Aramaki et al., 2013; Tanaka et al., 2013), Wnt5a, and its receptor Ror2, in migration (Laird et al., 2011; Chawengsaksophak et al., 2012), and Wnt4 in female sex-differentiation (Vainio et al., 1999; Chassot et al., 2012). Both the specification and sex-differentiation of PGCs utilize the $\beta$-catenin-dependent, canonical arm of the Wnt pathway (Chassot et al., 2008, 2011; Aramaki et al., 2013), while migration is regulated by the noncanonical Wnt pathway (Laird et al., 2011; Chawengsaksophak et al., 2012). Similar regulation of PGC migration by Wnts has been shown in Drosophila via $\mathrm{WntD}$ and is likely mediated through signaling independent of the canonical pathway (McElwain et al., 2011). Overactivation of the canonical Wnt pathway in post-migratory mouse PGCs has been shown to slow the cell cycle rate and reduce the size of the germ cell pool (Kimura et al., 2006).

\section{The noncanonical Wnt receptor Ror2}

As previously mentioned, noncanonical Wnt signaling is defined by the binding of Wnt to Frizzled and non-LRP receptors (Niehrs, 2012). One such receptor is Ror2, a tyrosine kinase-like receptor that is highly conserved and plays a critical role in the development of many organs and tissues (Minami et al., 2010). Ror-family members are found in invertebrate and vertebrate species ranging from C. elegans to humans (Forrester and Garriga 1997; Forrester et al., 1999; DeChiara et al., 2000; Oldridge et al., 2000; Takeuchi et al., 2000; Hikasa et al., 2002). The mammalian Ror2 protein consists of several domains including an extracellular cysteine-rich domain that is similar to those found in Frizzled proteins, an extracellular Kringle domain with unknown function in Ror2, an intracellular tyrosine kinase domain the phosphorylation of which is not always required for Ror2 signaling, and an intracellular proline-rich domain that binds cytoskeletal modifiers (Patthy et al., 1984; Oishi et al., 2003; Nishita et al., 2006; Liu et al., 2008). Loss of Ror2 in the mouse results in numerous developmental abnormalities including a shortened body axis, defects in limb and genital outgrowth, cleft palate, and respiratory and cardiac dysfunction that result in death shortly after birth (DeChiara et al., 2000; Takeuchi et al., 2000; Oishi et al., 2003). Similar defects are found in mouse mutants of Wnt5a, a classically described noncanonical Wnt and the most characterized ligand for Ror2 (Yamaguchi et al., 1999). Mutations in the human Ror2 locus are associated with Robinow syndrome, a disorder characterized by dwarfism, craniofacial defects, and genital hypoplasia (Afzal et al., 2000; van Bokhoven et al., 2000), and brachydactyly type $\mathrm{B}$, disorder in the growth of distal phalanges and nails (Oldridge et al., 2000; Schwabe et al., 2004).

Wnt5a and Ror2 have been shown to regulate many downstream signaling pathways. Work in cell lines identified a role for Wnt5a suppression of canonical Wnt signaling via Ror2 (Mikels and Nusse, 2006); this interaction between the Wnt pathways was confirmed in in vivo studies where loss of Ror2 lead to an increase in canonical Wnt activity (Mikels et al., 2009). Wnt5a-Ror2 have also been linked to the planar cell polarity (PCP) pathway through several in vivo studies. In the developing limb bud, Wnt5a is expressed in a gradient that corresponds with a gradient of phosphorylated Vang12, a core protein involved in PCP (Gao et al., 2011). This phosphorylation is mediated by Ror2. In the developing cochlea, Wnt5a regulates the polarized distribution of Vangl2 and maintains the polarity and organization of hair cells (Qian et al., 2007). Both groups also showed that Wnt5a;Vangl2 or Ror2;Vang12 double-mutant embryos failed to close the neural tube, a defect common to mutants of key 
PCP genes, further implicating Wnt5a-Ror2 in this pathway (Qian et al., 2007; Gao et al., 2011).

\section{Wnt5a-Ror 2 in cell migration}

In addition to regulation of planar cell polarity and suppression of canonical Wnt signaling, a majority of noncanonical Wnt signaling pathways have been linked to various forms and mechanisms of collective and single cell migration (Nishita et al., 2010). Work in numerous cell lines has identified Wnt5a-Ror2 as upstream regulators of cell migration through protrusion formation or calcium signaling and cell invasion via ECM degradation (Slusarski et al., 1997; Nishita et al., 2006; Enomoto et al., 2009). Downstream effectors of Wnt5a and Ror2 in these pathways include Dishevelled, JNK, c-Src, and Filamin A (Nishita et al., 2006; Akbarzadeh et al., 2008; Nomachi et al., 2008; O'Connell et al., 2009; Nishita et al., 2010b).

In vivo studies have identified a role for Ror2 in directing neuronal migration in $C$. elegans and Wnt5a-Ror2 in regulating convergent extension during gastrulation in X. laevis (Forrester and Garriga 1997; Forrester et al., 1999; Hikasa et al., 2002). Recent publications have further implicated Wnt5a-Ror2 in various processes of mammalian cell migration including mediation of chemotactic responses, convergent extension, and cell invasiveness in the palate, gut, and osteosarcoma lines, respectively ( $\mathrm{He}$ et al., 2008; Enomoto et al., 2009; Yamada et al., 2010). Ror2 as a biomarker and therapeutic target for metastatic cancers is also an active area of research (Morioka et al., 2009; Wright et al., 2009; Debebe and Rathmell, 2015).

\section{Wnt5a-Ror2 in PGC migration}

Our lab identified a recessive allele of Ror2 in a genome-wide ENU mutagenesis screen for genes involved in germ cell development, establishing the first connection between Ror2 and PGCs (Laird et al., 2011). In Ror $2^{\mathrm{Y} 324 \mathrm{C} / \mathrm{Y} 324 \mathrm{C}}$ (Ror2 ${ }^{\mathrm{Y} 324 \mathrm{C}}$ ) mutants, PGCs accumulated in ectopic and extra-gonadal locations and colonized the gonadal ridges with poor efficiency. Examination of cell shape (by elongation index, EI) and angle of cell axes in these Ror2-mutant PGCs ex vivo demonstrated an inability to elongate and orient appropriately in response to KitL, suggesting a cellular mechanism for their migratory defect. Measurements of E9.5 Ror2 ${ }^{\mathrm{Y} 324 \mathrm{C}}$ PGCs in vivo revealed elongation defects similar to those seen in vitro, with mutant PGCs adopting the rounded morphology of postmigratory WT PGCs that lost their motility after arrival in the gonads at E11.5. We recently found that the impaired migratory capacity of Ror $2^{\text {Y324C }}$ PGCs contributes to a failure to colonize the anterior tip of the gonadal ridges, and that this aberrant distribution of PGCs persists in the fetal ovary and leads to a delay in the initiation of meiosis across the population (Arora et al., 2016).
Together, these data show that Ror2-mutant PGCs are less competent to migrate during development, although the precise mechanism for this defect is unknown.

Wnt5a is similarly important in PGC migration and development, with mutants showing a more profound loss of germ cells colonizing the gonadal ridges than Ror $2^{\mathrm{Y} 324 \mathrm{C}}$ and disruption of testicular development in the male (Chawengsaksophak et al., 2012). Broad expression of Wnt5a in somatic tissues along the migratory route suggests that this ligand does not provide guidance cues to PGCs (Laird et al., 2011). This was confirmed by experiments in which Wnt5acoated beads did not divert PGCs from their migratory route (Laird et al., 2011). Interestingly, Wnt5a-coated beads implanted in the developing mouse palate induced attraction and directional migration of mesenchymal cells toward the beads (He et al., 2008); this Wnt5amediated migration was dependent on Ror2. Together, these studies raise the possibility that Wnt5a has chemotactic properties in some migratory contexts but not others.

In addition to facilitating PGC migration, recent studies suggest that the Wnt5a-Ror2 signaling axis plays an additional role in proliferation. Closer examination of Ror2 mutant PGCs revealed an elevation of cell cycle genes and overproliferation specifically in the hindgut, where WNT5A expression is highest. It was shown genetically that the $\beta$-catenin-dependent canonical pathway promotes proliferation and is repressed by Wnt5a via Ror2 in PGCs (Cantú et al., 2016). The implication is that Wnt5a and Ror2 function to balance movement with proliferation by toggling between different arms of the Wnt signaling pathway.

\section{Outstanding questions}

The studies on Wnt5a and Ror2 summarized above raise new questions, namely which aspects of cell migration are autonomous and which are regulated by the surrounding somatic environment. Ex vivo culture data suggested a PGC-autonomous role for Ror2 in regulating migration, but broad expression of the receptor and its ligand in somatic tissues of the embryo (Yamada et al., 2010; Laird et al., 2011) raise the possibility that Ror2 function in cells of the migratory niche might influence PGC motility and development. Since the precise signaling pathways by which the Wnt5a-Ror2 pathway regulates migratory PGCs were not previously identified, questions remain about how Wnt5a regulates PGC migration without providing directional cues and whether the canonical Wnt pathway is relevant to this period of germ cell development. The evolutionary conservation of Wnt5aRor2 signaling in PGC development remains to be seen through the study of other model organisms. Finally, the use of conditional alleles will bypass the lethality of loss of Wnt5a-Ror2 signaling and permit interrogation of the consequence of reduced motility of PGCs on fertility. 


\section{References}

Afzal AR, Rajab A, Fenske CD, Oldridge M, Elanko N, Ternes-Pereira E, Tuysuz B, Murday VA, Patton MA, Wilkie AO, Jeffery S. 2000. Recessive Robinow syndrome, allelic to dominant brachydactyly type B, is caused by mutation of ROR2. Nat Genet, 25:419-422.

Akbarzadeh S, Wheldon LM, Sweet SM, Talma S, Mardakheh FK, Heath JK. 2008. The deleted in brachydactyly B domain of ROR2 is required for receptor activation by recruitment of Src. PLoS One, 3:e1873.

Ancelin K, Lange UC, Hajkova P, Schneider R, Bannister AJ, Kouzarides T, Surani MA. 2006 Blimp1 associates with Prmt5 and directs histone arginine methylation in mouse germ cells. Nat Cell Biol, 8:623-630.

Anderson R, Fässler R, Georges-Labouesse E, Hynes RO, Bader BL, Kreidberg JA, Schaible K, Heasman J, Wylie C. 1999. Mouse primordial germ cells lacking betal integrins enter the germline but fail to migrate normally to the gonads. Development, 126:1655-1664.

Anderson R, Copeland TK, Schöler H, Heasman J, Wylie C. 2000. The onset of germ cell migration in the mouse embryo. Mech Dev, 91:61-68.

Ara T, Nakamura Y, Egawa T, Sugiyama T, Abe K, Kishimoto T, Matsui Y, Nagasawa T. 2003. Impaired colonization of the gonads by primordial germ cells in mice lacking a chemokine, stromal cell-derived factor-1 (SDF-1). Proc Natl Acad Sci USA, 100:5319-1523.

Aramaki S, Hayashi K, Kurimoto K, Ohta H, Yabuta Y, Iwanari H, Mochizuki Y, Hamakubo T, Kato Y, Shirahige K, Saitou M. 2013. A mesodermal factor, T, specifies mouse germ cell fate by directly activating germline determinants. Dev Cell, 27:516-529. Arora R, Abby E, Ross AD, Cantu AV, Kissner MD, Castro V, Ho HY, Livera G, Laird DJ. 2016. Meiotic onset is reliant on spatial distribution but independent of germ cell number in the mouse ovary. $J$ Cell Sci, 129:2493-2499.

Baronsky T, Dzementsei A, Oelkers M, Melchert J, Pieler T, Janshoff A. 2016. Reduction in E-cadherin expression fosters migration of Xenopus laevis primordial germ cells. Integr Biol (Camb), 8:349-358.

Behrens J, von Kries JP, Kühl M, Bruhn L, Wedlich D, Grosschedl R, Birchmeier W. 1996. Functional interaction of beta-catenin with the transcription factor LEF-1. Nature, 382:638-642.

Bendel-Stenzel MR, Gomperts M, Anderson R, Heasman J, Wylie C. 2000. The role of cadherins during primordial germ cell migration and early gonad formation in the mouse. Mech Dev, 91:143-152.

Berry M, Rogers AW. 1965. The migration of neuroblasts in the developing cerebral cortex. J Anat, 99:691-709.

Bialecka M, Young T, Chuva de Sousa Lopes S, ten Berge D, Sanders A, Beck F, Deschamps J. 2012. $\mathrm{Cdx} 2$ contributes to the expansion of the early primordial germ cell population in the mouse. Dev Biol, 371:227-234.

Blaser H, Eisenbeiss S, Neumann M, ReichmanFried M, Thisse B, Thisse C, Raz E. 2005. Transition from non-motile behaviour to directed migration during early PGC development in zebrafish. $J$ Cell Sci, 118:4027-4038.

Blaser H, Reichman-Fried M, Castanon I, Dumstrei K, Marlow FL, Kawakami K, Solnica-Krezel L, Heisenberg CP, Raz E. 2006. Migration of zebrafish primordial germ cells: a role for myosin contraction and cytoplasmic flow. Dev Cell, 11:613-627.

Buehr M, McLaren A, Bartley A, Darling S. 1993. Proliferation and migration of primordial germ cells in $W^{e} / W^{e}$ mouse embryos. Dev Dyn, 198:182-189.

Cantú AV, Altshuler-Keylin S, Laird DJ. 2016. Discrete somatic niches coordinate proliferation and migration of primordial germ cells via Wnt signaling, $J$ Cell Biol, 214:215-229.

Chaganti RS, Rodriguez E, Mathew S. 1994. Origin of adult male mediastinal germ-cell tumours. Lancet, 343:1130-1132.

Charras G, Sahai E. 2014. Physical influences of the extracellular environment on cell migration. Nat Rev Mol Cell Biol, 15:813-824.

Chassot AA, Ranc F, Gregoire EP, RoepersGajadien HL, Taketo MM, Camerino G, de Rooij DG, Schedl A, Chaboissier MC. 2008. Activation of beta-catenin signaling by Rspol controls differentiation of the mammalian ovary. Hum Mol Genet, 17:12641277.

Chassot AA, Gregoire EP, Lavery R, Taketo MM, de Rooij DG, Adams IR, Chaboissier MC. 2011. RSPO1/ $\beta$-catenin signaling pathway regulates oogonia differentiation and entry into meiosis in the mouse fetal ovary. PLoS One, 6:e25641.

Chassot AA, Bradford ST, Auguste A, Gregoire EP, Pailhoux E, de Rooij DG, Schedl A, Chaboissier MC. 2012. WNT4 and RSPO1 together are required for cell proliferation in the early mouse gonad. Development, 139:4461-4472.

Chawengsaksophak K, Svingen T, Ng ET, Epp T, Spiller CM, Clark C, Cooper H, Koopman P. 2012. Loss of Wnt5a disrupts primordial germ cell migration and male sexual development in mice. Biol Reprod, 86:1-12.

Chen CS, Alonso JL, Ostuni E, Whitesides GM, Ingber DE. 2003. Cell shape provides global control of focal adhesion assembly. Biochem Biophys Res Commun, 307:355-361.

Chen WT. 1981. Mechanism of retraction of the trailing edge during fibroblast movement. $J$ Cell Biol, 90:187-200.

Chiquoine AD. 1954. The identification, origin, and migration of the primordial germ cells in the mouse embryo. Anat Rec, 118:135-146.

Clark AG, Vignjevic DM. 2015. Modes of cancer cell invasion and the role of the microenvironment. Curr Opin Cell Biol, 36:13-22.

Clark JM, Eddy EM. 1975. Fine structural observations on the origin and associations of primordial germ cells of the mouse. Dev Biol, 47:136-155.

Coates TD, Watts RG, Hartman R, Howard TH. 1992. Relationship of F-actin distribution to development of polar shape in human polymorphonuclear neutrophils. J Cell Biol, 117:765-774 
Collazo A, Bronner-Fraser M, Fraser S. 1993. Vital dye labelling of Xenopus laevis trunk neural crest reveals multipotency and novel pathways of migration. Development, 118:363-376.

de Bruyn PPH. 1946. The amoeboid movement of the mammalian leukocyte in tissue culture. Anat Rec, 95:117-192.

De Felici M, Dolci S. 1989. In vitro adhesion of mouse fetal germ cells to extracellular matrix components. Cell Differ Dev, 26:87-96.

De Felici M, Dolci S, Pesce M. 1993. Proliferation of mouse primordial germ cells in vitro: a key role for cAMP. Dev Biol, 157:277-280.

De Felici M. 2011. Nuclear reprogramming in mouse primordial germ cells: epigenetic contribution. Stem Cells Int, 2011:425863.

de Melo Bernardo A, Sprenkels K, Rodrigues G, Noce T, Chuva De Sousa Lopes SM. 2012. Chicken primordial germ cells use the anterior vitelline veins to enter the embryonic circulation. Biol Open, 1:1146-1152. Debebe Z, Rathmell WK. 2015. Ror2 as a therapeutic target in cancer. Pharmacol Ther, 150:143-148.

DeChiara TM, Kimble RB, Poueymirou WT, Rojas J, Masiakowski P, Valenzuela DM, Yancopoulos GD. 2000. Ror2, encoding a receptor-like tyrosine kinase, is required for cartilage and growth plate development. Nat Genet, 24:271-274.

Di Carlo A, De Felici M. 2000. A role for E-cadherin in mouse primordial germ cell development. Dev Biol, 226:209-219.

Ding J, Jiang D, Kurczy M, Nalepka J, Dudley B, Merkel EI, Porter FD, Ewing AG, Winograd N, Burgess J, Molyneaux K. 2008. Inhibition of HMG $\mathrm{CoA}$ reductase reveals an unexpected role for cholesterol during PGC migration in the mouse. $B M C$ Dev Biol, 8:120.

Doitsidou M, Reichman-Fried M, Stebler J, Köprunner M, Dörries J, Meyer D, Esguerra CV, Leung T, Raz E. 2002. Guidance of primordial germ cell migration by the chemokine SDF-1. Cell, 111:647659.

Dolci S, Williams DE, Ernst MK, Resnick JL, Brannan CI, Lock LF, Lyman SD, Boswell HS, Donovan PJ. 1991. Requirement for mast cell growth factor for primordial germ cell survival in culture. Nature, 352:809-811.

Donovan PJ, Stott D, Cairns LA, Heasman J, Wylie CC. 1986. Migratory and postmigratory mouse primordial germ cells behave differently in culture. Cell, 44:831-838.

Dzementsei A, Schneider D, Janshoff A, Pieler T. 2013. Migratory and adhesive properties of Xenopus laevis primordial germ cells in vitro. Biol Open, 2:12791287.

Enomoto M, Hayakawa S, Itsukushima S, Ren DY, Matsuo M, Tamada K, Oneyama C, Okada M, Takumi T, Nishita M, Minami Y. 2009. Autonomous regulation of osteosarcoma cell invasiveness by Wnt5a/Ror2 signaling. Oncogene, 28:3197-3208.

Ephrussi A, Lehmann R. 1992. Induction of germ cell formation by oskar. Nature, 358:387-392.

Farini D, La Sala G, Tedesco M, De Felici M. 2007.
Chemoattractant action and molecular signaling pathways of Kit ligand on mouse primordial germ cells. Dev Biol, 306:572-583.

Ffrench-Constant C, Hollingsworth A, Heasman J, Wylie CC. 1991. Response to fibronectin of mouse primordial germ cells before, during and after migration. Development, 113:1365-1373.

Flanagan JG, Chan DC, Leder P. 1991. Transmembrane form of the kit ligand growth factor is determined by alternative splicing and is missing in the Sld mutant. Cell, 64:1025-1035.

Forrester WC, Garriga G. 1997. Genes necessary for C. elegans cell and growth cone migrations. Development, 124:1831-1843.

Forrester WC, Dell M, Perens E, Garriga G. 1999. A C. elegans Ror receptor tyrosine kinase regulates cell motility and asymmetric cell division. Nature, 400:881885.

Friedl P, Gilmour D. 2009. Collective cell migration in morphogenesis, regeneration and cancer. Nat Rev Mol Cell Biol, 10:445-457.

Friedl P, Wolf K. 2010. Plasticity of cell migration: a multiscale tuning model. J Cell Biol, 188:11-19.

Gao B, Song H, Bishop K, Elliot G, Garrett L, English MA, Andre P, Robinson J, Sood R, Minami Y, Economides AN, Yang Y. 2011. Wnt signaling gradients establish planar cell polarity by inducing Vang12 phosphorylation through Ror2. Dev Cell, 20:163-176.

García-Castro MI, Anderson R, Heasman J, Wylie C. 1997. Interactions between germ cells and extracellular matrix glycoproteins during migration and gonad assembly in the mouse embryo. J Cell Biol, 138:471-480.

Gat U, DasGupta R, Degenstein L, Fuchs E. 1998. De Novo hair follicle morphogenesis and hair tumors in mice expressing a truncated beta-catenin in skin. Cell, 95:605-614.

Gjorevski N, Piotrowski AS, Varner VD, Nelson CM. 2015. Dynamic tensile forces drive collective cell migration through three-dimensional extracellular matrices. Sci Rep, 5:11458.

Godin I, Deed R, Cooke J, Zsebo K, Dexter M, Wylie CC. 1991. Effects of the steel gene product on mouse primordial germ cells in culture. Nature, 352(6338):807-809.

Godin I, Wylie CC. 1991. TGF $\beta$ inhibits proliferation and has a chemotropic effect on mouse primordial germ cells in culture. Development, 113:1451-1457.

Gomperts M, García-Castro M, Wylie C, Heasman J. 1994. Interactions between primordial germ cells play a role in their migration in mouse embryos. Development, 120:135-141.

Gu Y, Runyan C, Shoemaker A, Surani A, Wylie C. 2009. Steel factor controls primordial germ cell survival and motility from the time of their specification in the allantois, and provides a continuous niche throughout their migration. Development, 136:1295-1303.

Gu Y, Runyan C, Shoemaker A, Surani MA, Wylie C. 2011. Membrane-bound steel factor maintains a high local concentration for mouse primordial germ cell motility, and defines the region of their migration. PLoS 
One, 6:e25984.

Hackett JA, Reddington JP, Nestor CE, Dunican DS, Branco MR, Reichmann J, Reik W, Surani MA, Adams IR, Meehan RR. 2012. Promoter DNA methylation couples genome-defence mechanisms to epigenetic reprogramming in the mouse germline. Development, 139:3623-3632.

Hackett JA, Sengupta R, Zylicz JJ, Murakami K, Lee C, Down TA, Surani MA. 2013. Germline DNA demethylation dynamics and imprint erasure through 5hydroxymethylcytosine. Science, 339:448-452.

Hart MJ, de los Santos R, Albert IN, Rubinfeld B, Polakis P. 1998. Downregulation of beta-catenin by human Axin and its association with the APC tumor suppressor, beta-catenin and GSK3 beta. Curr Biol, 8:573-581.

He F, Xiong W, Yu X, Espinoza-Lewis R, Liu C, Gu S, Nishita M, Suzuki K, Yamada G, Minami Y, Chen Y. 2008. Wnt5a regulates directional cell migration and cell proliferation via Ror2-mediated noncanonical pathway in mammalian palate development Development, 135:3871-3879.

Hegerfeldt Y, Tusch M, Bröcker EB, Friedl P. 2002. Collective cell movement in primary melanoma explants: plasticity of cell-cell interaction, beta1integrin function, and migration strategies. Cancer Res, 62:2125-2130.

Hikasa H, Shibata M, Hiratani I, Taira M. 2002. The Xenopus receptor tyrosine kinase Xror2 modulates morphogenetic movements of the axial mesoderm and neuroectoderm via Wnt signaling. Development, 129:5227-5239.

Huang EJ, Nocka KH, Buck J, Besmer P. 1992. Differential expression and processing of two cell associated forms of the kit-ligand: KL-1 and KL-2. Mol Biol Cell, 3:349-362.

Hynes RO. 2009. The extracellular matrix: not just pretty fibrils. Science, 326:1216-1219.

Izzard CS, Lochner LR. 1980. Formation of cell-tosubstrate contacts during fibroblast motility: an interference-reflexion study. J Cell Sci, 42:81-116.

Jaglarz MK, Howard KR. 1995. The active migration of Drosophila primordial germ cells. Development, 121:3495-3503.

Johnson GR, Moore MA. 1975. Role of stem cell migration in initiation of mouse foetal liver haemopoiesis. Nature, 258:726-728.

Kafri T, Ariel M, Brandeis M, Shemer R, Urven L, McCarrey J, Cedar H, Razin A. 1992. Developmental pattern of gene-specific DNA methylation in the mouse embryo and germ line. Genes Dev, 6:705-714.

Kamimura M, Ikenishi K, Kotani M, Matsuno $T$. 1976. Observations on the migration and proliferation of gonocytes in Xenopus laevis. J Embryol Exp Morphol, 36:197-207.

Kawase E, Hashimoto K, Pedersen RA. 2004. Autocrine and paracrine mechanisms regulating primordial germ cell proliferation. Mol Reprod Dev, 68:5-16.

Kimura T, Nakamura T, Murayama K, Umehara H, Yamano N, Watanabe S, Taketo MM, Nakano $T$. 2006. The stabilization of $\beta$-catenin leads to impaired primordial germ cell development via aberrant cell cycle progression. Dev Biol, 300:545-553.

Knaut H, Werz C, Geisler R, Nüsslein-Volhard C. 2003. A zebrafish homologue of the chemokine receptor Cxcr4 is a germ-cell guidance receptor. Nature, 421:279-282.

Korinek V, Barker N, Moerer P, van Donselaar E, Huls G, Peters PJ, Clevers H. 1998. Depletion of epithelial stem-cell compartments in the small intestine of mice lacking Tcf-4. Nat Genet, 19:379-383.

Koshimizu U, Watanabe M, Nakatsuji N. 1995. Retinoic acid is a potent growth activator of mouse primordial germ cells in vitro. Dev Biol, 168:683-685.

Kunwar PS, Sano H, Renault AD, Barbosa V, Fuse N, Lehmann R. 2008. Tre1 GPCR initiates germ cell transepithelial migration by regulating Drosophila melanogaster E-cadherin. J Cell Biol, 183:157-168.

Laird DJ, Altshuler-Keylin S, Kissner MD, Zhou X, Anderson KV. 2011. Ror2 enhances polarity and directional migration of primordial germ cells. PLoS Genet, 7:e1002428.

Laird DJ, von Andrian UH, Wagers AJ. 2008. Stem cell trafficking in tissue development, growth, and disease. Cell, 132:612-630.

Lämmermann T, Bader BL, Monkley SJ, Worbs T, Wedlich-Söldner R, Hirsch K, Keller M, Förster R, Critchley DR, Fässler R, Sixt M. 2008. Rapid leukocyte migration by integrin-independent flowing and squeezing. Nature, 453:51-55.

Lauffenburger DA, Horwitz AF. 1996. Cell migration: a physically integrated molecular process. Cell, 84:359-369.

Liu Y, Rubin B, Bodine PV, Billiard J. 2008. Wnt5a induces homodimerization and activation of Ror2 receptor tyrosine kinase. J Cell Biochem, 105:497-502.

Llense F, Martín-Blanco E. 2008. JNK signaling controls border cell cluster integrity and collective cell migration. Curr Biol, 18:538-544.

Lo CM, Wang HB, Dembo M, Wang YL. 2000. Cell movement is guided by the rigidity of the substrate. Biophys $J$, 79:144-152.

Logan CY, Nusse R. 2004. The Wnt signaling pathway in development and disease. Annu Rev Cell Dev Biol, 20:781-810.

Maatouk DM, Kellam LD, Mann MR, Lei H, Li E, Bartolomei MS, Resnick JL. 2006. DNA methylation is a primary mechanism for silencing postmigratory primordial germ cell genes in both germ cell and somatic cell lineages. Development, 133:3411-3418.

Matsui Y, Toksoz D, Nishikawa S, Nishikawa S, Williams D, Zsebo K, Hogan BL. 1991. Effect of Steel factor and leukaemia inhibitory factor on murine primordial germ cells in culture. Nature, 353:750-752.

McCoshen JA, McCallion DJ. 1975. A study of the primordial germ cells during their migratory phase in Steel mutant mice. Experientia, 31:589-590.

McCrea PD, Brieher WM, Gumbiner BM. 1993. Induction of a secondary body axis in Xenopus by antibodies to beta-catenin. $J$ Cell Biol, 123:477-484.

McElwain MA, Ko DC, Gordon MD, Fyrst H, Saba JD, Nusse R. 2011. A suppressor/enhancer screen in Drosophila reveals a role for wnt-mediated lipid 
metabolism in primordial germ cell migration. PLoS One, 6:e26993.

McLaren A. 2003. Primordial germ cells in the mouse. Dev Biol, 262:1-15.

McMahon AP, Moon RT. 1989. Ectopic expression of the protooncogene int-1 in Xenopus embryos leads to duplication of the embryonic axis. Cell, 58:1075-1084.

Metcalfe WK. 1985. Sensory neuron growth cones comigrate with posterior lateral line primordial cells in zebrafish. J Comp Neurol, 238:218-224.

Mikels AJ, Nusse R. 2006. Purified Wnt5a protein activates or inhibits beta-catenin-TCF signaling depending on receptor context. PLoS Biol, 4:e115.

Mikels AJ, Minami Y, Nusse R. 2009. Ror2 receptor requires tyrosine kinase activity to mediate Wnt5A signaling. J Biol Chem, 284:30167-30176.

Miller MJ, Wei SH, Cahalan MD, Parker I. 2003. Autonomous $\mathrm{T}$ cell trafficking examined in vivo with intravital two-photon microscopy. Proc Natl Acad Sci USA, 100:2604-2609.

Minami Y, Oishi I, Endo M, Nishita M. 2010. Rorfamily receptor tyrosine kinases in noncanonical Wnt signaling: their implications in developmental morphogenesis and human diseases. Dev Dyn, 239:1-15. Mintz B, Russell ES. 1957. Gene-induced embryological modifications of primordial germ cells in the mouse. J Exp Zool, 134:207-237.

Miyazawa K, Williams DA, Gotoh A, Nishimaki J, Broxmeyer HE, Toyama K. 1995. Membrane-bound Steel factor induces more persistent tyrosine kinase activation and longer life span of c-kit gene-encoded protein than its soluble form. Blood, 85:641-649.

Mizushima T, Nakagawa H, Kamberov YG, Wilder EL, Klein PS, Rustgi AK. 2002. Wnt-1 but not epidermal growth factor induces $\beta$-catenin/T-cell factordependent transcription in esophageal cancer cells. Cancer Res, 62:277-282.

Molenaar M, van de Wetering $M$, Oosterwegel $M$, Peterson-Maduro J, Godsave S, Korinek V, Roose J, Destrée O, Clevers H. 1996. XTcf-3 transcription factor mediates beta-catenin-induced axis formation in Xenopus embryos. Cell, 86:391-399.

Molyneaux KA, Stallock J, Schaible K, Wylie C. 2001. Time-lapse analysis of living mouse germ cell migration. Dev Biol, 240:488-498.

Molyneaux KA, Zinszner H, Kunwar PS, Schaible K, Stebler J, Sunshine MJ, O'Brien W, Raz E, Littman D, Wylie C, Lehmann R. 2003. The chemokine SDF1/CXCL12 and its receptor CXCR4 regulate mouse germ cell migration and survival. Development, 130:4279-4286.

Morioka K, Tanikawa C, Ochi K, Daigo Y, Katagiri T, Kawano H, Kawaguchi H, Myoui A, Yoshikawa H, Naka N, Araki N, Kudawara I, Ieguchi M, Nakamura K, Nakamura Y, Matsuda K. 2009. Orphan receptor tyrosine kinase ROR2 as a potential therapeutic target for osteosarcoma. Cancer Sci, 100:1227-1233.

Nakamura Y, Yamamoto Y, Usui F, Mushika T, Ono T, Setioko AR, Takeda K, Nirasawa K, Kagami H, Tagami T. 2007. Migration and proliferation of primordial germ cells in the early chicken embryo.
Poult Sci, 86:2182-2193.

Niehrs C. 2012. The complex world of WNT receptor signalling. Nat Rev Mol Cell Biol, 13:767-779.

Nishita M, Yoo SK, Nomachi A, Kani S, Sougawa N, Ohta Y, Takada S, Kikuchi A, Minami Y. 2006. Filopodia formation mediated by receptor tyrosine kinase Ror2 is required for Wnt5a-induced cell migration. J Cell Biol, 175:555-562.

Nishita M, Enomoto M, Yamagata K, Minami Y. 2010a. Cell/tissue-tropic functions of Wnt5a signaling in normal and cancer cells. Trends Cell Biol, 20:346354.

Nishita M, Itsukushima S, Nomachi A, Endo M, Wang Z, Inaba D, Qiao S, Takada S, Kikuchi A, Minami Y. 2010b. Ror2/Frizzled complex mediates Wnt5a-induced AP-1 activation by regulating Dishevelled polymerization. Mol Cell Biol, 30:36103619.

Nishiumi F, Komiya T, Ikenishi K. 2005. The mode and molecular mechanisms of the migration of presumptive PGC in the endoderm cell mass of Xenopus embryos. Dev Growth Differ, 47:37-48.

Nomachi A, Nishita M, Inaba D, Enomoto M, Hamasaki M, Minami Y. 2008. Receptor tyrosine kinase Ror2 mediates Wnt5a-induced polarized cell migration by activating c-Jun N-terminal kinase via actin-binding protein filamin A. $J$ Biol Chem, 283:27973-27981.

Nusse R, Varmus HE. 1982. Many tumors induced by the mouse mammary tumor virus contain a provirus integrated in the same region of the host genome. Cell, 31:99-109.

O'Connell MP, Fiori JL, Baugher KM, Indig FE, French AD, Camilli TC, Frank BP, Earley R, Hoek KS, Hasskamp JH, Elias EG, Taub DD, Bernier M, Weeraratna AT. 2009. Wnt5A activates the calpainmediated cleavage of filamin A. J Invest Dermatol, 129:1782-1789.

Ohinata Y, Ohta H, Shigeta M, Yamanaka K, Wakayama T, Saitou M. 2009. A signaling principle for the specification of the germ cell lineage in mice. Cell, 137:571-584.

Oishi I, Suzuki H, Onishi N, Takada R, Kani S, Ohkawara B, Koshida I, Suzuki K, Yamada G, Schwabe GC, Mundlos S, Shibuya H, Takada S, Minami Y. 2003. The receptor tyrosine kinase Ror2 is involved in non-canonical Wnt5a/JNK signalling pathway. Genes Cells, 8:645-654.

Oldridge M, Fortuna AM, Maringa M, Propping P, Mansour S, Pollitt C, DeChiara TM, Kimble RB, Valenzuela DM, Yancopoulos GD, Wilkie AO. 2000. Dominant mutations in ROR2, encoding an orphan receptor tyrosine kinase, cause brachydactyly type B. Nat Genet, 24:275-278.

Paluch EK, Raz E. 2013. The role and regulation of blebs in cell migration. Curr Opin Cell Biol, 25:582590 .

Pathak A, Kumar S. 2012. Independent regulation of tumor cell migration by matrix stiffness and confinement. Proc Natl Acad Sci USA, 109:10334-10339.

Patthy L, Trexler M, Váli Z, Bányai L, Váradi A. 1984. Kringles: modules specialized for protein binding. 
Homology of the gelatin-binding region of fibronectin with the kringle structures of proteases. FEBS Lett, 171:131-136.

Pelham RJ Jr, Wang Yl. 1997. Cell locomotion and focal adhesions are regulated by substrate flexibility. Proc Natl Acad Sci USA, 94:13661-13665.

Qian D, Jones C, Rzadzinska A, Mark S, Zhang X, Steel KP, Dai X, Chen P. 2007. Wnt5a functions in planar cell polarity regulation in mice. Dev Biol, 306:121-133.

Raz E. 2003. Primordial germ-cell development: the zebrafish perspective. Nat Rev Genet, 4:690-700.

Reichman-Fried M, Minina S, Raz E. 2004 Autonomous modes of behavior in primordial germ cell migration. Dev Cell, 6:589-596.

Resnick JL, Bixler LS, Cheng L, Donovan PJ. 1992. Long-term proliferation of mouse primordial germ cells in culture. Nature, 359:550-551.

Ricardo S, Lehmann R. 2009. An ABC transporter controls export of a Drosophila germ cell attractant. Science, 323:943-946.

Richardson BE, Lehmann R. 2010. Mechanisms guiding primordial germ cell migration: strategies from different organisms. Nat Rev Mol Cell Biol, 11:37-49.

Rousseau S, Houle F, Landry J, Huot J. 1997. p38 MAP kinase activation by vascular endothelial growth factor mediates actin reorganization and cell migration in human endothelial cells. Oncogene, 15:2169-2177.

Runyan C, Schaible K, Molyneaux K, Wang Z, Levin L, Wylie C. 2006. Steel factor controls midline cell death of primordial germ cells and is essential for their normal proliferation and migration. Development, 133:4861-4869.

Saitou M, Barton SC, Surani MA. 2002. A molecular programme for the specification of germ cell fate in mice. Nature, 418:293-300.

Scarpa E, Mayor R. 2016. Collective cell migration in development. J Cell Biol, 212:143-155.

Schwabe GC, Trepczik B, Suring K, Brieske N, Tucker AS, Sharpe PT, Minami Y, Mundlos S. 2004. Ror2 knockout mouse as a model for the developmental pathology of autosomal recessive Robinow syndrome. Dev Dyn, 229:400-410.

Seisenberger S, Andrews S, Krueger F, Arand J, Walter J, Santos F, Popp C, Thienpont B, Dean W, Reik W. 2012. The dynamics of genome-wide DNA methylation reprogramming in mouse primordial germ cells. Mol Cell, 48:849-862.

Seki Y, Hayashi K, Itoh K, Mizugaki M, Saitou M, Matsui Y. 2005. Extensive and orderly reprogramming of genome-wide chromatin modifications associated with specification and early development of germ cells in mice. Dev Biol, 278:440-458

Seki Y, Yamaji M, Yabuta Y, Sano M, Shigeta M, Matsui Y, Saga Y, Tachibana M, Shinkai Y, Saitou M. 2007. Cellular dynamics associated with the genome-wide epigenetic reprogramming in migrating primordial germ cells in mice. Development, 134:26272638.

Serbedzija GN, Fraser SE, Bronner-Fraser M. 1990 Pathways of trunk neural crest cell migration in the mouse embryo as revealed by vital dye labelling.
Development, 108:605-612.

Slusarski DC, Yang-Snyder J, Busa WB, Moon RT. 1997. Modulation of embryonic intracellular $\mathrm{Ca} 2+$ signaling by Wnt-5A. Dev Biol, 82:114-120.

Sonnenblick BP. 1941. Germ cell movements and sex differentiation of the gonads in the Drosophila embryo. Proc Natl Acad Sci USA, 27:484-489.

Starz-Gaiano M, Cho NK, Forbes A, Lehmann R. 2001. Spatially restricted activity of a Drosophila lipid phosphatase guides migrating germ cells. Development, 128:983-991

Starz-Gaiano M, Lehmann R. 2001. Moving towards the next generation. Mech Dev, 105:5-18.

Stebler J, Spieler D, Slanchev K, Molyneaux KA, Richter U, Cojocaru V, Tarabykin V, Wylie C, Kessel M, Raz E. 2004. Primordial germ cell migration in the chick and mouse embryo: the role of the chemokine SDF-1/CXCL12. Dev Biol, 272:351-361.

Su TT, Campbell SD, O'Farrell PH. 1998. The cell cycle program in germ cells of the Drosophila embryo. Dev Biol, 196:160-170.

Takeuchi S, Takeda K, Oishi I, Nomi M, Ikeya M, Itoh $K$, Tamura S, Ueda $T$, Hatta $T$, Otani $H$, Terashima T, Takada S, Yamamura H, Akira S, Minami Y. 2000. Mouse Ror2 receptor tyrosine kinase is required for the heart development and limb formation. Genes Cells, 5:71-78.

Tam PPL, Snow MHL. 1981. Proliferation and migration of primordial germ cells during compensatory growth in mouse embryos. J Embryol Exp Morphol, 64:133-147.

Tanaka SS, Nakane A, Yamaguchi YL, Terabayashi T, Abe T, Nakao K, Asashima M, Steiner KA, Tam PP, Nishinakamura R. 2013. Dullard/Ctdnep1 modulates WNT signalling activity for the formation of primordial germ cells in the mouse embryo. PLoS One, 8:e57428

Terayama K, Kataoka K, Morichika K, Orii H, Watanabe K, Mochii M. 2013. Developmental regulation of locomotive activity in Xenopus primordial germ cells. Dev Growth Differ, 55:217-228.

Thorpe JL, Doitsidou M, Ho SY, Raz E, Farber SA. 2004. Germ cell migration in zebrafish is dependent on HMGCoA reductase activity and prenylation. Dev Cell, 6:295-302.

Ulrich F, Krieg M, Schötz EM, Link V, Castanon I, Schnabel V, Taubenberger A, Mueller D, Puech PH, Heisenberg CP. 2005. Wnt11 functions in gastrulation by controlling cell cohesion through Rab5c and Ecadherin. Dev Cell, 9:555-564.

Vainio S, Heikkilä M, Kispert A, Chin N, McMahon AP. 1999. Female development in mammals is regulated by Wnt-4 signalling. Nature, 397:405-409

van Amerongen R, Nusse R. 2009. Towards an integrated view of Wnt signaling in development. Development, 136:3205-3214.

van Amerongen R, Fuerer C, Mizutani M, Nusse R. 2012. Wnt5a can both activate and repress Wnt/ $\beta$ catenin signaling during mouse embryonic development. Dev Biol, 369:101-114.

van Bokhoven H, Celli J, Kayserili H, van Beusekom E, Balci S, Brussel W, Skovby F, Kerr B, Percin EF, 
Akarsu N, Brunner HG. 2000. Mutation of the gene encoding the ROR2 tyrosine kinase causes autosomal recessive Robinow syndrome. Nat Genet, 25:423-426.

Van Doren M, Broihier HT, Moore LA, Lehmann R. 1998. HMG-CoA reductase guides migrating primordial germ cells. Nature, 396:466-469.

Vitorino P, Meyer T. 2008. Modular control of endothelial sheet migration. Genes Dev, 22:3268-3281.

Wang J, Sinha T, Wynshaw-Boris A. 2012. Wnt signaling in mammalian development: lessons from mouse genetics. Cold Spring Harb Perspect Biol, 4:a007963.

Warrior R. 1994. Primordial germ cell migration and the assembly of the Drosophila embryonic gonad. Dev Biol, 166:180-194.

Weidinger G, Wolke U, Köprunner M, Klinger M, Raz E. 1999. Identification of tissues and patterning events required for distinct steps in early migration of zebrafish primordial germ cells. Development, 126:5295-5307.

Weidinger G, Wolke U, Köprunner M, Thisse C, Thisse B, Raz E. 2002. Regulation of zebrafish primordial germ cell migration by attraction towards an intermediate target. Development, 129:25-36.

Weninger W, Biro M, Jain R. 2014. Leukocyte migration in the interstitial space of non-lymphoid organs. Nat Rev Immunol, 14:232-246.

Wouda RR, Bansraj MR, de Jong AW, Noordermeer JN, Fradkin LG. 2008. Src family kinases are required for WNT5 signaling through the Derailed/RYK receptor in the Drosophila embryonic central nervous system.
Development, 135:2277-2287.

Wright TM, Brannon AR, Gordan JD, Mikels AJ, Mitchell C, Chen S, Espinosa I, van de Rijn M, Pruthi R, Wallen E, Edwards L, Nusse R, Rathmell WK. 2009. Ror2, a developmentally regulated kinase, promotes tumor growth potential in renal cell carcinoma. Oncogene, 28:2513-2523.

Yamada M, Udagawa J, Matsumoto A, Hashimoto R, Hatta T, Nishita M, Minami Y, Otani H. 2010. Ror2 is required for midgut elongation during mouse development. Dev Dyn, 239:941-953.

Yamaguchi TP, Bradley A, McMahon AP, Jones S. 1999. A Wnt5a pathway underlies outgrowth of multiple structures in the vertebrate embryo. Development, 126:1211-23.

Yoon C, Kawakami K, Hopkins N. 1997. Zebrafish vasa homologue RNA is localized to the cleavage planes of 2- and 4-cell-stage embryos and is expressed in the primordial germ cells. Development, 124:31573165.

Young CS, Kitamura M, Hardy S, Kitajewski J. 1998. Wnt-1 Induces Growth, Cytosolic $\beta$-Catenin, and Tcf/Lef Transcriptional Activation in Rat-1 Fibroblasts. Mol Cell Biol, 18:2474-2485.

Zhang N, Zhang J, Cheng Y, Howard K. 1996. Identification and genetic analysis of wunen, a gene guiding Drosophila melanogaster germ cell migration. Genetics, 143:1231-1241.

Zhang N, Zhang J, Purcell KJ, Cheng Y, Howard K. 1997. The Drosophila protein Wunen repels migrating germ cells. Nature, 385:64-67. 